\title{
Mouse CD4 binds MHC class II with extremely low affinity
}

\author{
Susanna Weber and Klaus Karjalainen \\ Basel Institute for Immunology, Grenzacherstrasse 487, Postfach, CH-4005 Basel, Switzerland
}

Key words: adhesion, binding, co-receptor

\begin{abstract}
Interaction of CD4 with MHC class II molecules plays a crucial role durlng thymic development and activation of single-positlve CD4 $\mathrm{T}$ Iymphocytes. The quantitation of this interaction is, therefore, Important for understanding the role of CD4 during these events. To this end, we have developed a rosette assay, which enabled us to study thls molecular interaction. By coupling soluble mouse CD4 onto beads, we could show speclfic blnding of CD4 to MHC class II molecules on A20 B Iymphoma cells. These blnding studles revealed an extremely low aftinity $\left(K_{0} \leq 10^{4} \mathrm{M}^{-1}\right)$ between CD4 and MHC class II molecules In mouse.
\end{abstract}

The CD4 co-receptor is expressed on T cells which are MHC class II restricted and mostly of Thelper $\left(T_{h}\right)$ cell type $(1,2)$. CD4 is known to bind to a non-polymorphic determinant on MHC class II (2-6). Interaction of CD4 with MHC class II is crucial during thymic ontogeny (for review see 7 ) and plays a dual role in $T$ cell activation. First, by strengthening the overall interaction between $T_{h}$ cells and antigen presenting cells (APCs) $(8-10)$, and, second, by transducing signals to T cells (for review see 11).

The quantitation of this interaction would provide further insights into the complex interactions occuring in a TCR - CD3 - CD4 $\mathrm{MHC}$ plus peptide complex during antigen recognition by $\mathrm{T}$ cells and is of specific interest since the affinity of mouse TCR to MHC class II plus peptide was recently resolved to be about $10^{5} \mathrm{M}^{-1}$ $(12,13)$.

The direct binding of CD4 and MHC class II has been studied in the human system $(3,6)$, but no such studies are available for the corresponding murine molecules. Here, we report the development of an in vitro assay, with which direct and specific binding of mouse soluble CD4 (SCD4) to mouse MHC class II on the cell surface is demonstrated. This assay enabled us to estimate the affinity of mouse CD4 for MHC class II to be lower than $10^{4} \mathrm{M}^{-1}$. This further supports the hypothesis that the role of $\mathrm{CD} 4$ as a co-receptor probably is more important for signal transduction than adhesion.

To generate soluble CD4 molecules, i.e. $\mathrm{CD} 4-\mathrm{hC} \mu$ and CD4-C $x$, Ig expression vectors containing the cDNA for the extracellular part of the mouse CD4 gene and the $\mathrm{C}_{2}-\mathrm{C}_{4}$ exons of human $\mu$ heavy chain gene or the mouse $C_{x}$ exon of light chain genes were transfected into the myeloma cell line J558/L by protoplast fusion $(18,19)$. Stable transfectants were used for mass culture. $\mathrm{CD}_{4} \cdot \mathrm{hC} \mu$ was purified from concentrated supernatants by gel filtration, as described in Fig. 1, and CD4- $C_{x}$ by using affinity chromatography (19).

SDS - PAGE analysis of the materials used in this study showed that chimeric sCD4s of predicted molecular nature were produced. Non-reducing SDS-PAGE analysis revealed that $\mathrm{CD} 4 \cdot \mathrm{hC} \mu$ assembled into a typical pentameric structure of $\lg \mathrm{M}$ (Fig. 1), corresponding to a valency of 10 for the CD4 part, while CD4-Cx behaved as a monomer.

In addition, all tested mAbs (GK1.5 (20); H129 (21); and RM4-4 and RM4-5, both Pharmingen, San Diego, CA) against different CD4 epitopes recognized the CD4-C $\mu$ as well as the CD4-hCx protein. Reciprocally, antibodies raised against $\mathrm{CD} 4 \cdot \mathrm{hC} \mu$ and CD4- $\mathrm{C} x$ stained CD4 ${ }^{+} \mathrm{T}$ cells (data not shown). These results suggest that antigenically native $S C D 4 s$ are produced. However, the attempts to detect direct binding of the CD4-hC $\mu$ and $C D 4-C x$ to $\mathrm{MHC}$ class II positive cells failed consistently, presumably because of low affinity.

To test this hypothesis, we further increased the valency of sCD4 by coupling CD4-hC $\mu$ onto beads and performed a rosette assay by incubating CD4-hC $\mu$ - beads with $A 20$ cells, which are known to express high levels of MHC class II molecules (17). Subsequently, rosette formation was analysed by microscopy (Fig. 2). Most of the rosetted cells were completely covered by CD4-hC $\mu$-beads. To demonstrate that the 'bead-berries' are rosetted cells and not aggregated beads, cells were stained with acridine orange, as shown in Fig. 2(A and $B$ ).

The rosette formation was specific for the CD4-MHC class II interaction, since it was completely inhibited by anti-MHC class II mAb M5/114 (22) (Fig. 2 and Table 1). Irrelevant rat anti-mouse mAb (53-6.7) as well as an anti-MHC class I mAb (15.5.5s) did not inhibit rosette formation (summarized in Table 1). M5/114

Correspondence to: K. Karjalainen 


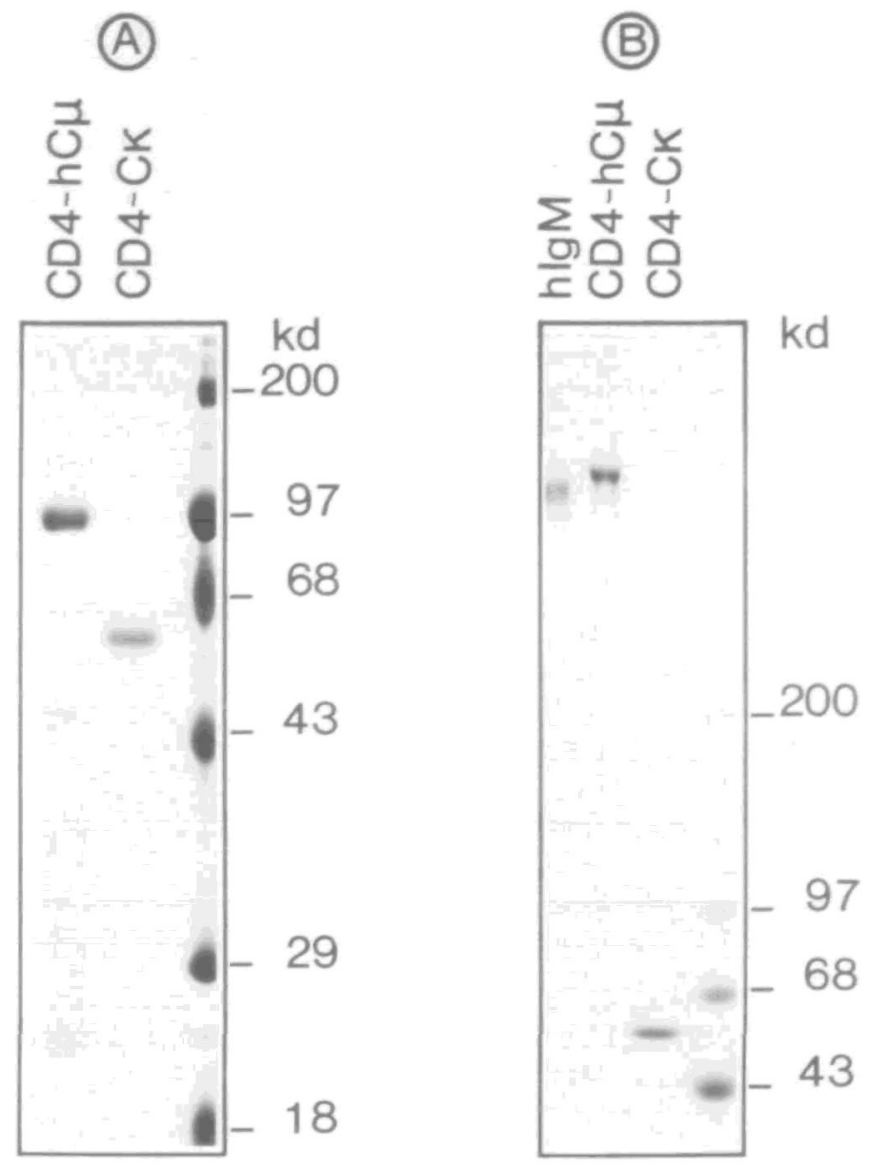

Fig. 1. SDS - PAGE analysis of CD4-hC $\mu$ and CD4-Cx. Purrfied CD4-hC $\mu$, CD4-C $x$, and, as a control, human $\lg M(\mathrm{~h} / \mathrm{gM})$ protein were analyzed by SDS - PAGE. The gels were subsequently stained with coomassie blue: (A) 7\% PA-gel, reducing condrions; (B) 3-10\% PA-gradient gel; non-reducing conditions. Standard molecular weight markers are indicated on the sides. Method: the part of the mouse CD4 (L3T4) CDNA sequence (14) coding for the extracellular region of the proten was engineered into $\mathrm{lg}$ expression vectors $(15,18)$ upstream of the $C_{2}-C_{4}$ exons of the human $\mu$ heavy chain gene or the $C$ exons of the mouse $x$ light chain gene The resulting constructs $\mathrm{pL} 3 \mathrm{~T} 4-\mathrm{hC} \mu$ and $\mathrm{pL} 3 \mathrm{~T} 4-\mathrm{C} x$ $(18,19)$ were introduced into the myeloma cell line $\mathrm{J} 558 / \mathrm{L}$ by protoplast fusion as described (16). Stable transfectants, secreting 2-6 mg/ CD4-hC $\mu$ were adapted to serum free medium (IMDM, $5 \mathrm{mg} /$ insulin, $5 \mathrm{mg} / \mathrm{transferrin}, 1 \times$ non-essential amino acids, $0.03 \%$ primatone). CD4-C $x$ was purfied from supernatant with an anti-mouse $\mathrm{C}_{x}$ affinity column and $\mathrm{CD}_{4} \cdot \mathrm{hC} \mu$ was purified from concentrated supernatant by gel-filtration with a FPLC superose 6 column (Pharmacia, Uppsala, Sweden).

recognizes an epitope on MHC class $\|$ involving $\beta_{1}$ and $\beta_{2}$ domains (R. König, personal communication) and is conserved in both MHC class II antigens, I-E and I-A. Consistent with this is the recent finding that part of the CD4 binding site to $\mathrm{MHC}$ class II molecules is located on the $\beta_{2}$ domain and that this binding site must also be conserved in I-E and I-A antigens. We then tried to carry out further epitope mapping by using a panel of additional anti-MHC class II mAbs. The mAb MKD6 reacting with I-A $\beta_{1}$ domain (23) and $m A b$ 14.4.4s, recognizing I-E $\alpha$ as well as two other mAbs, AMS-16 (anti-I-E) and AMS-32-1 (anti-IA), with undefined epitopes were used. None of the I-E- or

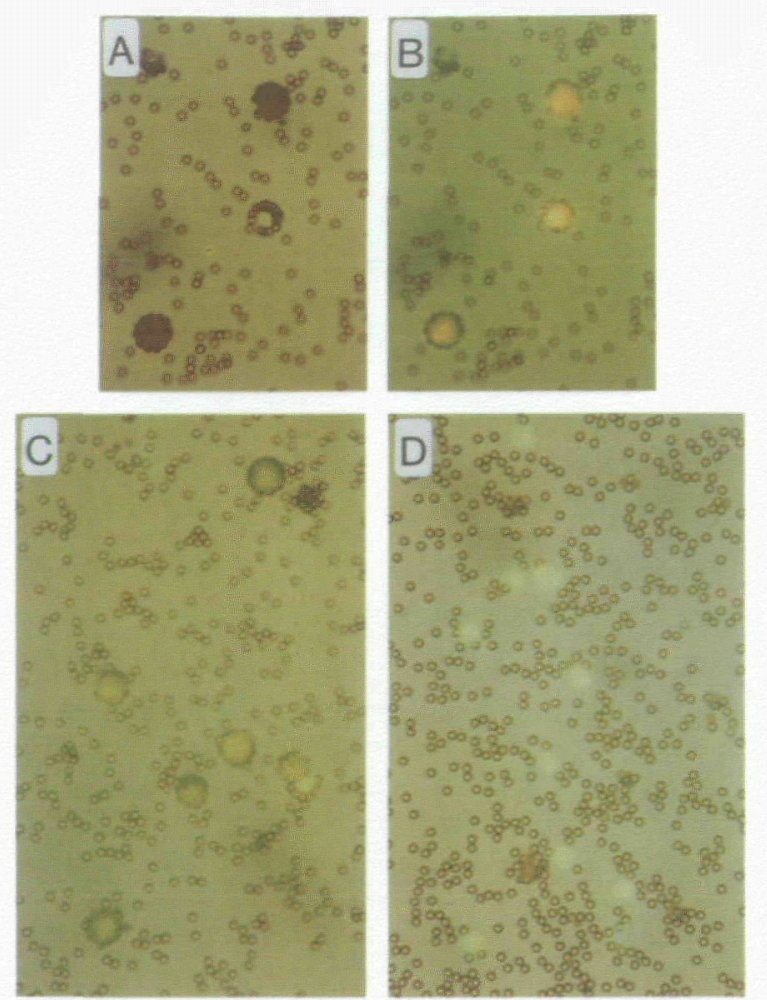

Fig. 2. Rosette formation. A20 cells were incubated with CD4-hC $\mu$-beads; subsequently, the cells were staned with acridine orange The comparison of $(A)$ light micrograph only versus $(B)$ light micrograph overlaid by fluorescence micrograph reveals that most of the rosetted A20 cells are completely covered by the beads. (C) Rosette formation of $\mathrm{A} 20$ cells with $\mathrm{CD} 4-\mathrm{hC} \mu$ - beads. (D) Complete inhibition of rosette formation by anti-MHC class II mAb (M5/114, $20 \mu \mathrm{g} / \mathrm{ml})(\times 400)$. Method. $\mathrm{CD} 4-\mathrm{hC} \mu$-beads were prepared by coupling polyclonal anthuman IgM antibodies (Jackson Immunoresearch, West Grove, PA) onto tosylactivated Dynabeads M-450 (Dynal, Oslo, Norway) overnight, in $0.5 \mathrm{M}$ borate buffer $\mathrm{pH} 9.5$ at $4^{\circ} \mathrm{C}$. Washed Dynabeads were then incubated with puritied $\mathrm{CD} 4-\mathrm{hC} \mu$ overnight in PBS/0 $1 \%$ BSA at $4^{\circ} \mathrm{C}$. The beads were washed and resuspended in medium (IMDM/5\% FCS) to a concentration of $4 \times 10^{8}$ beads $/ \mathrm{ml}$. The resulting beads (CD4-hC $\mu$-beads) have thus a layer of $\mathrm{CD} 4$, which is oriented to the outside and has a high density of CD4. For negative controls, anti-human IgM - beads were loaded the same way with human IgM (Chemicon, Temecula, CA). The rosette formation assay was performed by mixing $10 \mu$ of CD4-h $C_{\mu}$ - bead suspension $\left(4 \times 10^{\mathrm{B}} / \mathrm{ml}\right)$ with $50 \mu \mathrm{A} 20$ cell $(17)$ suspension $\left(2 \times 10^{6} / \mathrm{ml}\right.$, IMDM $/ 5 \%$ FCS), followed by incubation at room temperature for $1-2 \mathrm{~h}$ with continuous shaking. To distinguish between bead-covered cells and aggregated beads, the cells were stained with acridine orange. Analysis of rosette formation was performed in a hematocytometer by simultaneous light and fluorescence microscopy. Cetts with more than five attached beads were counted as rosetted cells. The percentage of rosetted cells varied from 40 to $90 \%$ of total cells between assays. Antt-human IgM-coupled beads and beads loaded with human $\lg \mathrm{M}$ protein were included in each assay as negative controls.

I-A-specific mAbs, nor the combination of I-E- and I-A-specific mAbs had inhibitory effects on rosette formation at concentrations up to $250 \mathrm{nM}(40 \mu \mathrm{g} / \mathrm{ml})$. In contrast, $\mathrm{M} 5 / 114$ inhibited rosette formation completely at concentrations of $15 \mathrm{nM}(2 \mu \mathrm{g} / \mathrm{ml})$. Thus, it seems that only mAb M5/114 binds MHC class II at an epitope interferring with the interaction of CD4.

Interestingly, although we failed to show direct binding, 
Table 1. Specific inhibition of the CD4 - MHC class II interaction

\begin{tabular}{|c|c|c|}
\hline Addition of & $\begin{array}{l}\text { Inhibition of } \\
\text { rosette formation }\end{array}$ & Reference \\
\hline None & no & - \\
\hline Rat ant-1-E/I-A & completely & M5/114 (22) \\
\hline Rat anti-CD8 & no & $53-5.7(30)$ \\
\hline Mouse anti-H-2 & no & $15.5 .5 \mathrm{~s}(31)$ \\
\hline Mouse anti-I-E & no & $\begin{array}{l}\text { 14.4.4s (30) and AMS-16 } \\
\text { (Pharmingen) }\end{array}$ \\
\hline Mouse anti-1-A & no & $\begin{array}{l}\text { MKD6 (32) and AMS-32.1 } \\
\text { (Pharmingen) }\end{array}$ \\
\hline $\begin{array}{l}\text { Mouse anti-I-E plus } \\
\text { Mouse ant-I-A }\end{array}$ & no & as above \\
\hline $\mathrm{CD} 4-\mathrm{hC}_{\mu}$ & completely & - \\
\hline $\mathrm{CD} 4 \cdot \mathrm{C}_{x}$ & no & - \\
\hline Human IgM & no & (Chemicon) \\
\hline
\end{tabular}

A20 cells $\left(H \cdot 2^{\dagger}\right)$ were preincubated with different antibodies and SCD4 before performıng rosette formation assay. Non-blocking antibodies had concentrations up to $250 \mathrm{nM}(40 \mu \mathrm{g} / \mathrm{ml})$, except human IgM and CD4-C $x_{1}$ where concentrations up to $2 \mathrm{mg} / \mathrm{ml}$ respectively did not inhibit rosette formation.

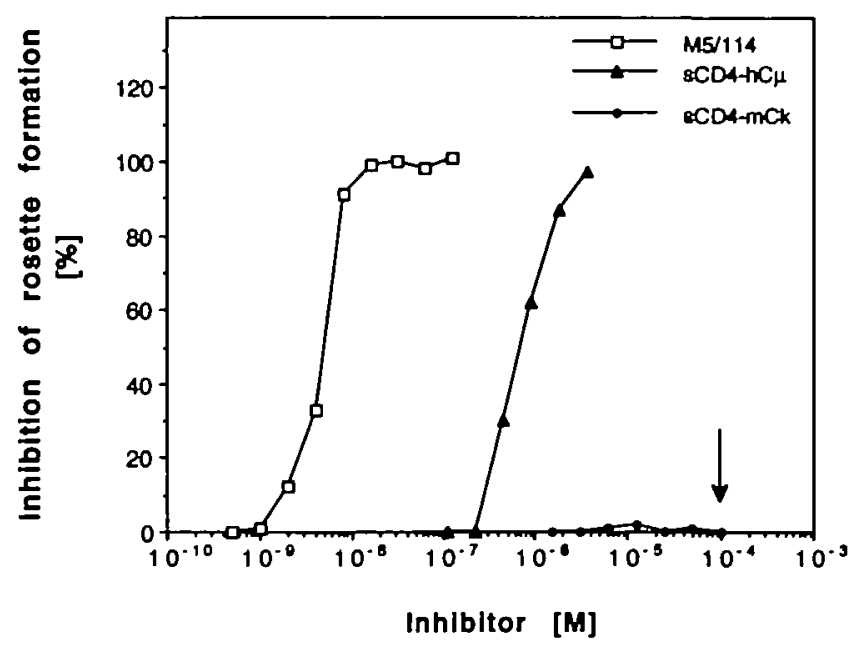

Fig. 3. Inhibition assay of rosette formation. A20 cells were preincubated with serial dilutions of anti-MHC class II mAbs (M5/114), CD4-hC $\mu$ or $\mathrm{CD} 4-\mathrm{C} x$ before addition of $\mathrm{CD}_{4}-\mathrm{hC} \mu$ - beads for the rosette formation assay. The arrow indicates the endpoint of CD4-Cx titration. Inhibition was standardized to rosette formation without any inhibitor (0\%). A typical example of such an inhibition assay is presented here. Variation between assays was very small.

$\mathrm{CD} 4-\mathrm{hC}_{\mu}$ completely inhibited rosette formation, most likely because no washing steps are needed for specific rosette formation. Control human $\mathrm{lgM}$ did not inhibit rosette formation, indicating that binding of $\mathrm{CD}_{4}-\mathrm{hC}_{\mu}$-beads to $\mathrm{A} 20$ cells is mediated by the $\mathrm{CD} 4$ part of the chimeric molecule. Complete inhibition of rosette formation by $\mathrm{CD}_{4}-\mathrm{hC}_{\mu}$ was obtained at concentrations of about $4 \mu \mathrm{M}$. Importantly, a monovalent form of CD4, CD4-Cx, was not observed to inhibit the rosette formation at up to $100 \mu \mathrm{M}(4 \mathrm{mg} / \mathrm{ml})$. We attribute these findings to the increased avidity of the pentameric $\mathrm{CD} 4-\mathrm{hC} \mu$, due to its multivalency compared with monovalent CD4-Cx. In fact, the pioneering work of Karush has shown that multivalency of $\operatorname{lgM}$ can increase the avidity up to $10^{7}$-fold compared with monovalent affinity (24).

The concentration values needed for $50 \%$ inhibition of the rosette formation can be used to estimate the affinity or avidity of an inhibitor (Fig. 3). This is illustrated by the fact that bivalent M5/114 mAb inhibits $50 \%$ of the rosette formation at about $5 \times 10^{-9} \mathrm{M}$ (Fig. 3), the value, which corresponds exactly to the avidity of the bivalent antibody measured by classical Scatchard analyses, $K_{\mathrm{a}} \sim 5 \times 10^{9} \mathrm{M}^{-1}$ (21 and our unpublished results). Thus, the avidity of CD4-hC $\mu$ is estimated to be about $7 \times 10^{7}$ $\mathrm{M}^{-1}$, since a 100 -fold higher concentration of $\mathrm{CD}_{4}-\mathrm{hC}_{\mu}$ is needed for inhibition of rosette formation compared with M5/114. Since extrapolation of affinities from avidity values is not possible (24), we can confidently estimate the upper limit for $K_{\mathrm{a}}$ to be $10^{4}$ $\mathrm{M}^{-1}$ or below from the fact that the monovalent form of SCD4 did not inhibit rosette formation at concentrations of $100 \mu \mathrm{M}$ $\left(10^{-4} \mathrm{M}\right)$. This value is in agreement with more indirect estimates of Hussey et al. (24) in the human system, but much lower than the affinity $\left(K_{\theta}=3 \times 10^{6} \mathrm{M}^{-1}\right)$ measured by Cammarota $e t$ al. (6), again for the human CD4-MHC class II interaction. The latter authors used both $\mathrm{SCD} 4$ and soluble $\mathrm{MHC}$ class II molecules to derive their affinity values, and it is conceivable that soluble MHC class II molecules are more accessible to SCD4 than MHC class II molecules embedded in the membrane. This may also explain why human sCD4 has never been shown directly to bind MHC class II positive cells.

CD4 has been proposed to have two different roles in antigenspecific interaction between $T_{h}$ cells and APCs: firstly, CD4 as an accessory molecule is thought to contribute to the general adhesion between $T_{h}$ cells and APCs $(8-10)$, and, secondly, CD4 as a co-receptor for TCR has been suggested to be essential for optimal $T_{h}$ cell actıvation, due to its signal transducing capabilities (for review, see 11). Based on our results, we think that CD4 makes only a very minor contribution to the general adhesion, since the other adhesion systems used by $T_{h}$ cells, like CD2/LFA-3 and LFA-1/ICAM, have affinities of at least two orders of magnitude higher than that of $C D 4 / \mathrm{MHC}$ class II molecules (26). Therefore, we reason that the co-receptor function is most likely physiologically more significant. Interestingly, it has been shown that CD4 can associate with TCR complexes $(27-29)$ and thus, presumably, it has some affinity to the TCR complex as well. Therefore, due to this dual binding specificity of CD4, it may exhibit much higher affinity to the TCR - CD3MHC plus peptide complex, as opposed to its affinities to either TCR - CD3 or MHC class II molecules alone. This would also explain why the CD4, as a signalling molecule during $T$ cell activation, can find its relevant partner in the presence of an excess of potentially irrelevant MHC class II and TCR molecules.

\section{Acknowledgements}

We would like to thank D. Avila for technical help with FPLC, and Drs W. Gerhard, P. Lane, and T. Rolink for critical reading of the manuscript. The Basel Institute for Immunology was founded and is supported by F. Hoffmann-La Roche Lid, Basel, Switzerland. 


\section{Abbrevlations}

APC

SCD4

$T_{h}$

antigen presentung cell

soluble CD4

$T$ helper cell

\section{Reterences}

1 Swain, S. 1983. T cell subsets and the recognition of MHC class. Immunol. Rev 74:129.

2 Wilde, D., Marrack, P., Kappler, J., Dialynas, D., and Fitch, F. 1983 Evidence implicating L3T4 in class II MHC antigen reactivity; monoclonal antibody GK1.5 (anti-L3T4a) blocks class II MHC antigenspecific proliferation, release of lymphokines, and binding by cloned murine helper T lymphocyte lines. J. Immunol. 131:2178.

3 Doyle, C. and Strominger, J. 1987. Interaction between CD4 and class II MHC molecules mediates cell adhesion. Nature 330.256

4 Gay, D., Buus, S., Pasternack, J., Kappler, J., and Marrack, P. 1988. The T-cell accessory molecule CD4 recognizes a monomorphic determinant on isolated la. Proc. Natl Acad. Sci. USA 85:5629

5 König, R., Huang, L.-Y., and Germain, R. 1992. MHC class II interaction with $\mathrm{CD} 4$ mediated by region analogous to the MHC class I binding site for CD8. Nature 356:796.

6 Cammarota, G., Scheirle, A., Takacs, B., Doran, D., Knorr, R., Bannwarth, W., Guardiola, J, and Sinigaglia, F. 1992. Identification of a CD4 binding site on the $\beta_{2}$ domain of HLA-DR molecules. Nature 356:799.

7 von Boehmer, H., Kisielow, P., Kishi, H., Scott, B., Borgulya, P., and Teh, H. 1989. The expression of CD4 and CD8 accessory molecules on mature $T$ cells is not random but correlates with the specificity of the $\alpha \beta$ receptor for antigen. Immunol. Rev. 109:143.

8 Marrack, P., Endres, R., Shimonkevitz, R., Zlotnik, A , Dtalynas, D., Fitch, F., and Kappler, J. 1983. The major histocompatibility complexrestricted antigen receptor on T cells. II. Role of the L3T4 product J. Exp. Med 158:1077.

9 Biddison, W., Rao, P., Talle, M., Goldsteın, G., and Shaw, S. 1984. Possible involvement of the T4 molecule in T cell recognition of class II HLA antigens. Evidence from studies of CTL-target cell binding. J. Exp. Med. 159:783.

10 Gay, D., Maddon, P., Sekaly, R., Talle, M A., Godfrey, M., Long, E., Goldstein, G., Chess, L., Axel, R., Kappler, J., and Marrack, P. 1987. Functional interaction between human $\mathrm{T}$ cell protein $\mathrm{CD} 4$ and the major histocompatibility complex HLA-DR antigen. Nature 328:626.

11 Janeway, C. 1992. The T cell receptors as a multicomponent signalling machine $\mathrm{CD} 4 / \mathrm{CD} 8$ coreceptors and CD45 in T cell activation. Annu. Rev. Immunol. 10:645.

12 Weber, S., Traunecker, A., Orveri, F., Gerhard, W., and Karjalainen, K. 1992. Specific low-affinity recognition of major histocompatibility complex plus peptide by soluble T-cell receptor. Nature 356:793.

13 Matsui, K., Boniface, J., Reay, P., Schild, H., Fazekas de St. Groth, B., and Davis, M. 1991. Low affinity interaction of peptide-MHC complexes with T cell receptor. Science 254:1788.

14 Littman, D. and Gettner, S. 1987. Unusual intron in the immunoglobulin domain of the newly isolated murine CD4 (L3T4) gene. Nature $325 \cdot 453$.

15 Rutschmann, R. and Karjalainen, K. 1991. Mouse LFA-3 studied with chimeric soluble CD2 shows preferential expression on lymphoid cells. Eur. J Immunol. 21:1379

16 Oi, V. T., Morrisson, S. L., Herzenberg, L. A., and Berg, P. 1983 Immunoglobulin gene expression in transtected lymphoid celts Proc. Natl Acad. Sci. USA 80:825.

17 Walker, E., Warner, N. Chestnut, R, Kappler, J., and Marrack, P. 1982. Antigen specific, I-region restricted interactions in vitro between tumor cell lines and T cell hybridomas. J. Immunol. 128:2164.

18 Traunecker, A., Dolder, B., Oliveri, F., and Karjalainen, K. 1989. Solubilizing the T-cell receptor-problems in solution. Immunol. Today 10:29

19 Weber, S., Traunecker, A., and Karjalainen, K. 1993. Constitutive expression of high levels of soluble mouse CD4 in transgenic mice does not interfere with their immune function. Eur. J. Immunol, 23:511.

20 Dialyas, D., Quan, Z., Wall, K., Pierres, A., Quintás, J., and Loken, M. 1983. Characterization of the murine $T$ cenl surface molecule, designated L3T4, identified by monoctonal antibody GK 1.5: similarity of L3T4 to the human Leu-3/T4 molecule. J. Immunol. 131:2445.

21 Pierres, A., Naquet, P., Van Agthoven, A , Bekkhoucha, F., Denizot, F., Mishal, Z. Schmitt-Verhulst, A and Pierres, M. 1984. A rat anti-mouse T4 monochonal antibody $(\mathrm{H} 129.19)$ inhibrts the prolferation of la-reactive $T$ cell clones and delineates two phenotypically distinct $\left(\mathrm{T4}^{+}, \mathrm{Lyt}^{-2,3^{-}}\right.$, and $\left.\mathrm{T4}^{-}, \mathrm{Lyt} 2,3^{+}\right)$subsets among anti-lg cytolytic T cell clones. J. Immunol. 132.2775

22 Bhattacharya, A., Dorf, M., and Springer, T. 1981. A shared alloantigenic determinant on la antigens encoded by I-A and I-E subregıons: Evidence for I region gene duplication. J. Immunol. 127:2488.

23 Braunstein, N. and Germain. R. 1987. Allele-specific control of la surface expression and conformation: Implications for a general model of la structure-function relationship Proc. Natt Acad. Sci USA 84.2921.

24 Karush, F. and Hornick, C 1972. Multivalence and affinity of antibody. int. Arch. Allergy 45:130.

25 Hussey, R., Richardson, N., Kowalski, M., Brown, N., Chang, H.-C. Silicano, R., Dortman, T , Walker, B., Sodroski, J., and Reinherz, E. 1988. A soluble CD4 protein selectively inhibits HIV replication and syncytium formation. Nature $331: 78$.

26 Springer, T. 1990. Adhesion receptors of the immune system. Nature 346:425.

27 Anderson, P., Blue, M., and Schlossman, S. 1988. Comodulation of $\mathrm{CD} 3$ and $\mathrm{CD} 4$. Evidence for a specific assoctation between $\mathrm{CD} 4$ and approximately $5 \%$ of the CD3:T cell receptor complexes on helper T lymphocytes. J. Immunol. 140:1732.

28 Rojo, J., Saizawa, K., and Janeway, C. 1989. Physical interaction of CD4 and the T cell receptor can be induced by anti-T cell receptor antibodies. Proc. Natl Acad. Sci. USA 86:3311.

29 Saizawa, K., Rojo, J., and Janeway, C. 1987. Evidence for a physical association of CD4 and the CD3: $\alpha: \beta$ T cell receptor. Nature 260.

30 Ledbetter, J. A. and Herzenberg, L. A. 1979. Xenogenic monoclonal antibodies to mouse lymphoid differentiation antigens. Immunol Rev. 47:63.

31 Ozato, K., Mayer, N., and Sachs, D. 1980. Hybridoma cell lines secreting monoclonal antibodies 10 mouse $\mathrm{H}-2$ and la antigens. J. Immunol. 124.533.

32 Kappler, J., Skidmore, B., White, J., and Marrack, P. 1981. Antigen inducible, H-2-restricted, interleukin-2-producing T cell hybridomas. J. Exp. Med. 153:1198 